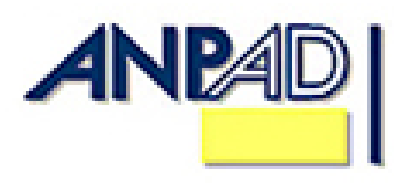

Available online at

http://www.anpad.org.br/bar

BAR, Rio de Janeiro, v. 10, n. 3, art. 4, pp. 304-322, July/Sept. 2013

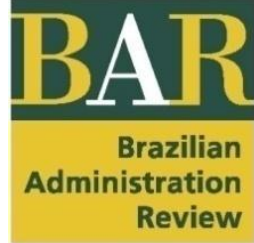

$(\mathrm{coc}) \mathrm{E}$

\title{
From Garment to Fashion Production: An Analysis of the Evolution of the Apparel Industry in Brazil
}

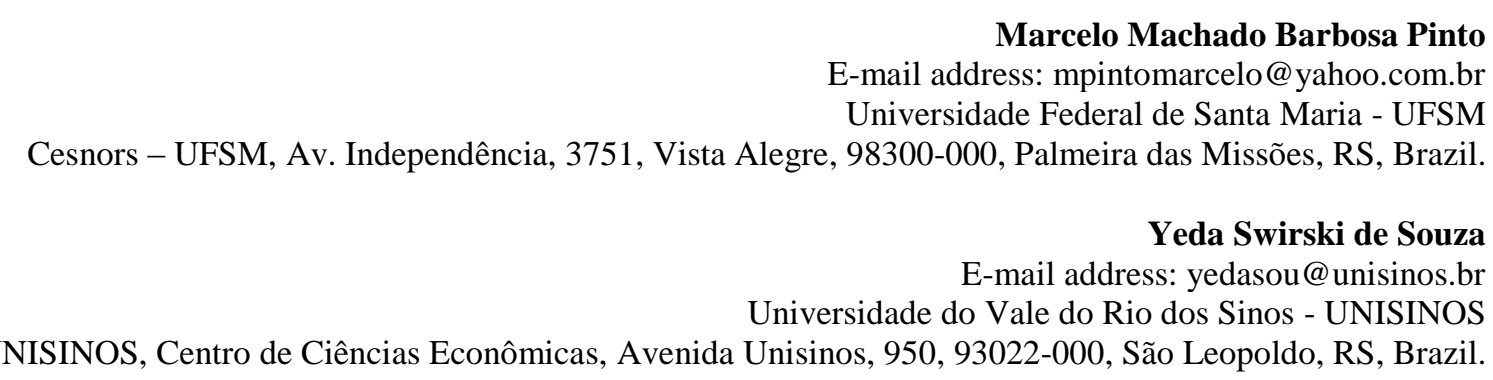

Received 26 August 2012; received in revised form 27 January 2013; accepted 4 March 2013, published online $1^{\text {st }}$ July 2013.

Editor's note. José Pla Barber served as Associate Editor for this article. 


\begin{abstract}
This study aims at contributing to the analysis of the evolution of apparel industry in Brazil by answering the following questions: (a) Does global sourcing still explain the value upgrading process in the apparel production chains?; (b) Are there new sources of value upgrading to be considered?; (c) Is the dynamics of the apparel production pervaded by a phenomenon that is strongly related to a cultural and creative know-how? Two theoretical approaches are considered to unveil the value upgrading process in the apparel production: (a) theory about global value chains and (b) studies about cultural and creative industries. To investigate the research questions we analyzed the case of the Brazilian apparel industry evolution through the use of a methodological perspective nurtured by aspects of grounded theory. The findings of this study indicate that companies are able to upgrade not only through improvements in manufacturing steps but also by means of incorporating elements of cultural distinction in the apparel production. Analysis of the Brazilian case led us to propose an integrative theoretical approach where elements of the global apparel value chains are combined with studies of cultural and creative industries. We consider that an integrative approach can better explain value creation in the apparel industry in a context of new markets, where there is not only the development of apparel manufacturing clusters but also the emergence of a unique and local fashion apparel chain.
\end{abstract}

Key words: fashion; fashion apparel; global apparel value chain; fashion apparel value chain; cultural economy. 


\section{Introduction}

In the last two decades the apparel industry has evolved in terms of manufacturing and retailing. This evolution is depicted in several studies that highlight the relocation of manufacturing across the apparel commodity chain as well as strategic moves of the main players of the apparel industry in a globalization process (Buxey, 2005; Gereffi, Humphrey, \& Sturgeon, 2005; Pickles \& Smith, 2011; Sammarra \& Belussi, 2006; Schmitz \& Knorringa, 2000).

Global value chains in the apparel industry have been preliminarily motivated by the search for cost advantages. The relocation of manufacturing from the US and the EU to other countries where labor has been less costly is a phenomenon observed since the 1970s (Berger, 2006; Bonacich \& Waller, 1994; Jacobides \& Billinger, 2006).

Apparel retailing has also been evolving due to the emergence of new markets, e.g. Brazil, Russia, India and China (Markusen, Wassall, DeNatale, \& Cohen, 2008; Nika, 2010; Pontual, 2011; Prideaux, 2009), and the employment of new techniques for attracting consumer, e.g. fast fashion and rapid replenishment (Abernathy, Dunlop, Hammond, \& Weil, 1999; Ferdows, Lewes, \& Machuca, 2004; Michault, 2009; Richardson, 1996).

In emerging markets like Brazil, the evolution and relocation of the apparel industry has contributed to the establishment of sophisticated manufacturing clusters and to the rise of big box retailers. Several academic articles have stressed different aspects about the evolution of apparel industry from traditional manufacturing to the multinational enterprise based on global value chain production and retailing (Bonacich \& Waller, 1994; Gereffi \& Memedovic, 2003; Schmitz \& Knorringa, 2000). Nevertheless this literature does not cover a variation of the evolution of the apparel industry that has been observed in Brazil where there is the emergence of a unique and local fashion apparel chain (Pinto, 2011; Pinto \& Souza, 2011; Pontual, 2010). The evidence of this local evolution indicates that a new lens is required to understand an ongoing local phenomenon of upgrading apparel production. As reminded by Abernathy, Dunlop, Hammond and Weil (1999), apparel production involves several processes that lead to different products identified as fashion, fashion-basic and basic products. These processes engage distinct companies and guide them to different strategies. We found in Brazil several small and medium-sized companies producing and retailing based upon various business models (Costa \& Rocha, 2009). There is also a set of companies devoted to fashion production which are embedded in a local and growing creative industry, such as the case of beachwear production (Pinto \& Souza, 2011).

The identification of this local evidence sparks the questions driving this paper: Does global sourcing still explain the value upgrading process in the apparel production chain? Are there new sources of value upgrading to be considered? Is the dynamics of apparel production pervaded by a phenomenon that is strongly related to a cultural and creative know-how?

This paper ${ }^{(1)}$ is organized as follows: the first section presents the introduction. The next section describes the literature review from which we draw upon the evolution of the apparel industry, highlighting the tangible and the intangible nuances of apparel production. The third section describes the research methods. The fourth section presents the results and the discussion from which we draw forth an alternative approach to explain the evolution of the apparel industry in Brazil. The final section presents the conclusions of this study.

\section{Literature Review}

This study is based on two theoretical approaches that consider the evolution of the apparel industry. The first one is aligned with studies of global apparel value chains and call attention to the 
industrial upgrading process that emphasizes the tangible production of apparel items (AbecassisMoedas, 2006; Abernathy et al., 1999; Abernathy, Volpe, \& Weil, 2005; Bonacich \& Waller, 1994; Cheng \& Gereffi, 1994; Ferdows et al., 2004; Gereffi, 1999; Gereffi et al., 2005; Gereffi \& Memedovic, 2003; Jacobides \& Billinger, 2006; Porter, 1990; Rabellotti, 2003; Sammarra \& Belussi, 2006; Schmitz \& Knorringa, 2000). We consider this approach to be the manufacturing approach. The second one is aligned with studies of cultural and creative industries and recognizes the cultural upgrading process that highlights the intangible production of a fashion concept or belief (Cholachatpinyo, Padgett, Crocker, \& Fletcher, 2002; Currid, 2006, 2007; Djelic \& Ainamo, 1999; Kawamura, 2006; Rantisi, 2002, 2004; Richardson, 1996; Skov, 2006; Uzzi, 1996, 1997; Williams \& Currid-Halkett, 2011). Henceforth, we name this approach the cultural approach.

\section{The evolution of the apparel industry: supplying global value chains}

The manufacturing approach assumes that the apparel value chain is a process by which technology is combined with materials and labor and then processed, assembled, distributed and marketed. Furthermore, this approach assumes that upgrading occurs to products that are organizationally related through lead firms in global value chains (Gereffi, 1999). So, apparel manufacturers from emerging countries (e.g. Brazil) need to follow this value chain process in order to upgrade. The manufacturing approach reveals export models from emerging countries, for instance, original equipment manufacturing (OEM) and original brand name manufacturing (OBM) (Gereffi, 1999; Gereffi et al., 2005). OEM is characterized as a step up from a mere assembly of imported inputs (exporting processing zones) to a more integrated and skill-intensive activity of supplying goods and services in domestic and overseas markets. OBM is characterized as an export model that goes beyond OEM by joining production expertise in a learning manner with the design and sale of branded merchandise.

According to Jacobides and Billinger (2006), the main functions associated with apparel production can be depicted in the following schema (Figure 1). This flow is a mix of tangible and intangible value activities usually performed by different players that look for specific strategies aiming at creating and capturing value.

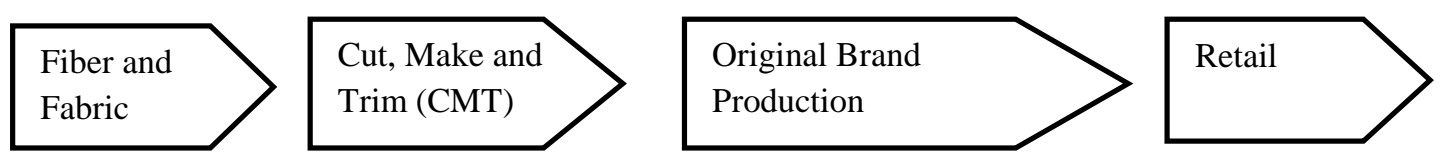

Figure 1. Main Apparel Value Chain Activities.

Source: Adapted from Jacobides and Billinger (2006, p. 253).

Gereffi (1999) considers the global apparel value chain to be a buyer-driven linear chain. In this configuration, leading companies (large retailers or/and branded marketers or/and branded manufacturers) control apparel chains, getting their main income from providers/followers who work in this value chain, such as traders, overseas buyers, licensed manufacturers, etc. Companies that negotiate prestigious brands or/and manufacture famous brands or/and sell huge amounts of goods to consumers make the rules. The main decisions taken by the coordinators of the apparel chain are associated with the choice of suppliers that are able to deliver orders to retail stores in time and with competitive prices. Low value-added contractors often attempt to incorporate value-added productive activities that were originally developed or controlled by the coordinator (usually large retailers). Thus, a supplier that was initially an assembler of components supplied by the coordinator would then start to produce these components. By doing this the supplier upgrades its role in the value chain stream. A low value-added supplier would increase its knowledge about the process in order to obtain higher revenue as part of the chain flow.

However, the potential for follow-up companies' to upgrade in global apparel chains is limited, mainly for the followers that usually perform tangible value-adding tasks. According to Rabellotti 
(2003), there are examples of industrial downgrading in companies that abandoned design and sale inputs when they join apparel value chains as manufacture contractors.

Gereffi (1999) suggests that apparel economic surplus is concentrated in the nodes of the chain where market power is stronger. On the retail side, giant discounters, national merchandise chains, warehouse clubs, and other large buyers account for the lion's share of the orders in the U.S. and European apparel market. They use their leverage to press for compliance from domestic as well as overseas apparel manufacturers. Unlike producer-driven value chains, in which supply factors largely determine the nature of demand, in the buyer-driven apparel chains the decisions made by big buyers (usually retailers) shape the global apparel value chains (Gereffi, 1999; Gereffi \& Memedovic, 2003).

In this approach the upgrading of a participant company is primarily associated with the shift from assembly to full-package production. Compared with the mere assembly of imported inputs, fullpackage production fundamentally changes the relationship between buyers and suppliers in a direction that gives the supplying firm a far greater autonomy and learning potential for method upgrading. Full-package production becomes more frequent due to the fact that most retailers and marketers that order apparel are no longer able to manufacture them (Cheng \& Gereffi, 1994; Gereffi et al., 2005).

Gereffi and Memedovic (2003) consider that large retailers in general lead the process towards mass customization and agile manufacturing. These authors state that there has been a striking merger as well as a growth in the retail segment of buyer-driven value chains in the United States. Meanwhile apparel manufacturers in Europe and Japan have become even more fragmented. While retailing and marketing is becoming more concentrated, manufacturing is splintering. To a certain degree, this trend is propelled by the information revolution that gives retailers better day-to-day market information about consumer purchasing decisions. This information allows retailers to demand more from their suppliers in terms of inventory management, quick response, more frequent deliveries, etc. As an implication of these dynamics, retailers are improving private label collections as an invigorating strategy that turns them into competitors, rather than customers, of traditional apparel manufacturers and designers.

Usually, retailers do not have production experience and they are dependent upon the suppliers, both domestically and in their global sourcing networks. Cost has been the main drive for supply decisions in this chain. Consequently, some strategies for adding value have been observed on the vendor side. In Asia, a number of manufacturers are integrating forward from specification contracting, such as original equipment manufacturing (OEM) or full-package functions, to developing and selling their own private labels, such as the original brand name manufacturing (OBM) function. In the U.S, textile companies are forming production groups with local apparel firms in Mexico to assure themselves of a customer base. Thus, a growing concentration at the retail end of the apparel value chains is generating networks of collaborators as well as competitors in the upstream segments of the chains (Gereffi \& Memedovic, 2003).

In summary, the studies about the global apparel value chain indicate that the evolution of the apparel industry is based on a buyer-driven rationale, which means that large retailers or/and brand marketers or/and brand manufacturers perform a pivotal role in the chain since concentration grows downstream. This reasoning also point out that apparel manufacturers spread out in different countries, mainly in Central and Latin America, East Europe and Asia, where they are increasingly aligned with global apparel chains which determine that upgrading of a participant manufacturer is primarily associated with the shift from assembly to full-package production.

\section{The fashion apparel: the emergence of a cultural industry}

A preliminary assumption on establishing relationships between cultural and creative industries and the evolution of the apparel industry is that fashion plays a very important role in value adding to apparel production and retailing. The cultural approach considers value adding activities and upgrading processes in the context of creative embedded systems. It assumes that fashion is a concept 
and fashion apparel is a practice or phenomenon. In this approach fashion must be considered a concept in a broader sense, to favor the understanding of what fashion apparel means in a sociological sense (Kawamura, 2006). Fashion as a concept must be distinguished from other expressions which are often identified as synonyms of fashion, such as clothing and garments. Those expressions refer to tangible objects while fashion is an intangible object. Trying to define a particular item of cloth as fashion is futile because fashion is not a material product but a symbolic product which has no content substance by/in itself (Currid, 2007; Kawamura, 2006).

From a cultural and creative industry perspective upgrading in apparel production is a process that involves an array of different players who potentially provide additional layers or degrees of intangible value to apparel items. This upgrading process has strong ties with social networking. According to Uzzi (1997), there is a notion that economic action in the fashion industry is embedded in social structure. Based on the players' networking, he found that an information structure emerges as a particular style, which is the fusion of components from different fashions, materials, nomenclatures, and production techniques.

Social networking prevails in the fashion industry world. One expression is the meetings organized by players/connectors such as fashion magazine editors in fashion hub cities which become social circuits. Dinner parties gather prestigious fashion designers, flagship store directors, costume designers, fashion producers, movie directors, movie stars, singers, art designers and a cohort of acquaintances and friends interested in doing business. In the fashion system, power is often measured in terms of the social circuit. The prevalence of aspects related to cultural relationships characterizes this organizational structure. Fashion is embedded in intangible value from a cultural and creative economy where a circuitous line leads to value-added products such as fashion apparel (Currid, 2006, 2007; Rantisi, 2002).

Following the cultural approach we understand that fashion emerges as a socio-culturally constructed meaning in specific urban contexts where different cultural expressions and the creative industry establish an intense interaction. Cultural worlds are constructed through interpretations, experiences and activities whereby material (i.e. apparel) is produced and consumed. Consequently, cultural objects, such as fashion apparel, can be analyzed from both/either production and/or consumption perspectives. Likewise, fashion can be a matter of collective production, distribution and sale, and also a matter of personal consumption and identity.

Currid (2007) emphasizes the significance of an informal social production system for disseminating ideas that propel a cultural economy in New York City. Currid (2006) and Rantisi (2002, 2004) point out the cultural vitality of the NYC's garment district, which boosts ideas and innovations for high-end fashion apparel. These studies clarify how several people or/and organizations find the credibility to crown a dress or a shoe with the approval and the cachet that make it worth wearing. This can lead to an effective intangible value-adding process to a piece of apparel.

Rantisi (2002), Currid (2006) and Markusen, Wassall, DeNatale and Cohen (2008) bring examples of unconventional and peripheral activities related to art trends that influence the production of fashion apparel by shedding light on the cultural and creative economy for companies that supply apparel components. These samples also unfold the upgrading process of an intangible value system or network structure identified as the cultural approach. It has implications on the intermediate players and consequently the fashion apparel players. These implications are going to be discussed in the Section Results: an Overview of the Brazilian Apparel Industry.

There are signs that intangible fashion value is weakening the traditional (buyer-driven) power of coordination in apparel value chains. For a long time, retail chain stores have kept their own fashion style creation teams but now agreements between these big-box buyers/retailers and independent fashion designers and/or private label marketers are becoming common. For instance, by 2004, Hennes and Mauritz (H\&M) started a partnership with Karl Lagerfeld and recently H\&M has launched new ventures with Sonia Rykiel and Jimmy Choo. Such associations give fashion higher profile for $\mathrm{H} \& \mathrm{M}$ and generate a new business model for the fashion apparel value chain where designer 
collaboration counts heavily. Most recent ventures between big-box retailers and fashion designers include Stella McCartney with The Gap and Rodarte with Target (Michault, 2009). In Brazil, for example, there were recent connections between Osklen and Riachuelo (Pontual, 2010) and between Cris Barros and Riachuelo (Pontual, 2011). The association between retailers, fashion designers and brand companies indicate the power of the social circuit as a source able to materialize intangible value/identity into fashion apparel production.

Fashion can be considered as a source of identity as it is socially recognized as a sign of selfrecognition. Fashion identity carries intangible value which is enacted in a social and cultural realm. The gathering of creative people who are devoted to different art expressions establishes an atmosphere in which production and legitimization of fashion trends come up. The French Riviera affected Coco Chanel's marine style, and New York City motivates several fashion designers in their collections, e.g. Calvin Klein, Diane von Furstenberg, Donna Karan and Kate Spade (Tungate, 2008).

As an active player in the fashion apparel industry, fashion designers should bear in mind that those who approve and seal fashion items are tastemakers and/or gatekeepers and they often show up at social meetings (Kawamura, 2006). According to Currid (2007) these people spend a lot of time in the social realm. They, along with all the other creative people who also thrive in the social life of a fashion hub city, give meaning to a world that outsiders think of as frivolous, superficial, or filled with cute people who have nothing to say. Creative fashion designers are also present in the social circuit of fashion hub cities, such as Paris, New York, London and Milan. Being among a town's celebrity brokers and society hostesses can allow some fashion designers to be introduced to people that have the credibility to crown fashion items with the approval and the seal that make them worth wearing and buying. So, a fashion designer will have the opportunity to show his/her work and, who knows, even be accepted to a project runway where in fact his/her collection will or won't be given aesthetic value by experts.

As an example, most of Alexander McQueen credit was ascribed to Isabella Blow, former editor of Tatler Magazine. Vogue America fashion director Sally Singer and Paper Magazine editor Kin Hastreiter have also contributed to the reputation of many American fashion designers such as Donna Karan, Michael Kors, Marc Jacobs and Zac Posen (Trebay, 2010).

Based on the theoretical assumptions revealed in the studies about the fashion production and consumption, named the cultural approach, we note that upgrading in the apparel value chains can also be explained by creative expertise which raises and captures intangible value. These activities rely on a fashion system that is an institutional-driven network which shows that fashion is elaborated by organizational and institutional factors.

\section{Approach and Method}

To investigate the proposed questions we adopted a case study perspective (Yin, 2006) nurtured by aspects of grounded theory (Charmaz, 2006). We considered as unit of analysis not only the organizational level but also the interorganizational one as proposed by Abecassis-Moedas (2006) in her investigation of value chains.

The extant theoretical approaches (the manufacturing approach and the cultural approach) analyze the evolution of the apparel industry and state assumptions about this process. Considering these assumptions we made an immersion in the field by collecting data from many sources in order to criticize the theory and to obtain information. This information helped us to question our findings by propelling an inductive and deductive process of analysis by way of determining if the extant propositions are sufficiently explicative or whether some other set of alternative explanations could be more relevant to clarify the object under examination (the upgrading process). 
We gathered secondary and primary data about apparel and fashion apparel production, retailing and consumption in Brazil. The choice for the Brazilian case considers the presence of a fully established apparel industry in the country, which is segmented into companies that can be classified at different levels of specialization and capabilities. Moreover, since the 1970s, several of these companies have contributed as suppliers in global value chains (Schmitz \& Knorringa, 2000).

Primary data was obtained from interviews with chief executive officers (CEOs) and commercial representatives of Brazilian fashion apparel companies; fashion designers; fashion editors and stylists. Secondary data was obtained from fashion editorials of Brazilian and U.S. fashion magazines and comprises data found in the electronic media such as interviews and tweets with fashion VIPs, fashion designers, and fashion magazine editors. Field observations were also performed in Brazil and in the U.S.

After being recorded, data from personal interviews, electronic media and loci observations were organized in a collection of texts (descriptions, narratives and transcriptions). These texts were analyzed following the theoretical propositions that led to the case design. We utilized the software NVIVO 9 as an attempt to organize, combine and classify data.

We adopted a descriptive and interpretative research approach to handle data. This procedure helped us to identify the connections between the fashion apparel players and led us to draw a sketch of the structure and dynamic of the fashion apparel in the studied case. This sketch aims at clarifying how the players acquire and manage both the intangible and tangible value for creation, production, promotion, distribution and consumption of fashion apparel items.

In the first stage, data was analyzed considering categories framed by the extant literature (manufacturing approach and cultural approach). In the second stage, inductive findings draw forth new categories. Furthermore, inductive findings led the authors to propose an alternative approach identified as the intermediate fashion apparel chain as well as its related supposition. Table 1 presents a summary of the categories and subcategories investigated and main functions of the players.

Table 1

Categories, Subcategories Investigated and Main Functions

\begin{tabular}{lll}
\hline Categories & Main Subcategories Studied & \multicolumn{1}{c}{ Main Functions } \\
\hline & $\begin{array}{l}\text { Traders and overseas buyers; } \\
\text { Licensed apparel manufacturers (contractors); } \\
\text { Apparel retailers and store-brand marketers. }\end{array}$ & Manufacturing and selling apparel; \\
Manufacturing players & $\begin{array}{l}\text { Fashion shows and fashion producers or stylists; } \\
\text { Fashion designers; }\end{array}$ & \\
Fashion media; & Fashion apparel production \& \\
Fashion groups; & $\begin{array}{l}\text { Fashion apparel manufacturers and retailers; } \\
\text { Textile mills. }\end{array}$ \\
Cultural players & $\begin{array}{l}\text { Designers; } \\
\text { Costume designers; } \\
\text { Entertainers; } \\
\text { Photographers; } \\
\text { Artists. }\end{array}$ & Fashion production \& consumption \\
\hline
\end{tabular}

While refining data from the previously categories mentioned (manufacturing, cultural and intermediate players), we found group (a) to be players who were mostly involved with apparel 
manufacturing steps and/or apparel selling and who were attached to a linear apparel value chain. These are traders and overseas buyers, licensed apparel manufacturers and apparel retailers and/or store-brand marketers. We considered them to be subcategories of manufacturing players. The next group (b) consisted of players who were partially involved with fashion apparel design and institutional image-making steps and partially involved with apparel manufacturing steps (private label projects - other players). These players were considered as hybrid and belonging to a diversified fashion apparel chain. These include fashion shows and fashion producers or stylists, fashion designers, fashion media, fashion groups, fashion apparel manufacturers, fashion apparel retailers and textile mills. We considered group (b) to be subcategories of intermediate players. Finally, group (c) was composed of players who were occasionally or rarely involved with fashion apparel manufacturing steps and totally or partially involved with fashion apparel consumption. These players belong to a fashion system. They are designers, costume designers, entertainers, photographers and artists. We considered these players as subcategories of cultural players. However it must be mentioned that there is an overlap of activities performed by some players.

\section{Results: an Overview of the Brazilian Apparel Industry}

In the presentation of data, we focused on the intermediate players as a way to depict the emerging approach of upgrading in the apparel chain. Our data showed that the intermediate players are those who are simultaneously involved with intangible value creation and with mechanical steps of tangible value apparel production. They are simultaneously connected with different providers (manufacturing and fashion players) to elaborate fashion apparel items.

The growing importance of the textile and apparel industry in the Brazilian economy can be better understood through some figures. In 2004 exports surmounted US $\$ 2.13$ billion. During the same year the sector generated a surplus of US\$ 656 million and created more than 66,000 job openings in the country. In 2006, the total turnover of the industry attained US $\$ 33$ billion. In 2008 the estimated earnings of the textile and apparel chain was US $\$ 43$ billion, a $4 \%$ growth compared to 2007 , which recorded US $\$ 41.3$ billion. The average apparel production in 2008 was 9.8 billion pieces, a $4 \%$ increase over 2007 which registered 9.5 billion pieces. The Brazilian textile and apparel industry aims at recovering its $1 \%$ share of the world market, which is equivalent to increasing the volume of exports up to US\$ 4 billion per year (Associação Brasileira da Indústria Têxtil e de Confecção [ABIT], 2013). Brazil has the world's ninth highest gross domestic product - US\$1.976 trillion - measured by purchasing power parity in 2008 (World Bank, 2010) but it is considered a relatively closed economy. Its international trade accounted for $24 \%$ of its gross domestic product in 2008 (Prideaux, 2009). The country shared only $1.2 \%$ of the world's export market in 2009, exporting US\$154 billion and ranking at the $24^{\text {th }}$ position, but it is the world's leading exporter of coffee, orange juice, sugar, ethanol, tobacco and chicken meat (Dantas et al., 2010). These facts indicate that Brazil is a large exporter of mass-produced unspecialized and low value-added products that needs to diversify its exports, especially by introducing distinguished and higher value-added products as a way to increase its products' prices and gain a higher position in the world's export rank.

Efforts have been made by Brazilian governmental agencies such as Apex, which promotes the Grupo Gestor Moda (Fashion Manager Group), an initiative that involves 2,141 companies, US\$120 million in projects and US\$92 million in promotional aid (Agência Brasileira de Promoção e Exportações e Investimento, n.d.).

The rise of fashion groups like InBrands and the outcome of some enterprises like Design Brazil from the Brazilian Footwear Association (Abicalçados) are signs that the apparel industry in Brazil is changing shape. Both initiatives are intended to push the Brazilian fashion apparel export average price from a single-digit to a double-digit or even to a triple-digit increase. This new apparel industry dynamic suggests a complex array of players who provide value-added services primarily for the domestic and then the international market. 


\section{The intermediate fashion apparel chain and its players}

\section{Fashion shows}

The initial attempts to authorize and legitimize the Brazilian fashion apparel through a institutionalized fashion organization have roots in São Paulo and Rio de Janeiro in the 1990s. Contemporary Brazilian fashion apparel shows debuted in São Paulo in the 1990s. The Phytoervas Fashion, a cultural event conceived to promote new fashion designers, arose in the city of São Paulo in 1993. At this time, a group of young fashion designers, including Gloria Coelho, Alexandre Herchcovitch and Ronaldo Fraga, composed a team that brought to the scene a new image of a fashion thanks to Phytoervas Cosmetics. Before the 1990s, the references of fashion for apparel manufactured in Brazil came from the European market. Exceptionally, few Brazilian fashion allusions were ascribed to Fenit, a traditional textile trade fair that began in 1958. The business of Brazilian fashion was so primitive that its agents had never even imagined a brand-name concept for it. For several decades Brazilian media made their fashion editorials based on the European aesthetic. Brazilian fashion designers were used to following trends dictated by the textile industry established in developed markets. Brazilian fashion, at that time, lacked the exploration of the cultural universe in its own country. Therefore, fashion designers, models, fashion producers, stylists and fashion editors emerged to fulfill the modern Brazilian fashion industry that was on the rise. At that time the Phytoervas Fashion was broadcast live on MTV Brasil (Pasqual, 2010).

In 1996, one of the lead promoters of Phytoervas Fashion, Paulo Borges, realized that there was room for a fashion week in Brazil. So, his group of fashion players started to organize the Morumbi Fashion that succeeded Phytoervas Fashion. At that time, with the support of the Morumbi Shopping Center, Morumbi Fashion hosted four fashion shows daily for an audience of approximately 300 people. This event rocketed the careers of some Brazilian fashion designers, such as Ricardo Almeida, Ronaldo Fraga and Reinaldo Lourenço. The fashion shows also launched famous models, including Gisele Bündchen, Ana Claudia Michels and Isabeli Fontana. Meanwhile, under Fernando Collor's presidency, Brazil started to open its market for imports. This openness moved Brazilian textile and apparel manufacturers to invest in technology in order to face foreign fashion apparel goods imported by major brand companies such as Chanel and Versace, who came to Brazil in the 1990s (Pasqual, 2010).

In 2001, Morumbi Fashion was renamed São Paulo Fashion Week (SPFW) and the Brazilian fashion calendar was settled. However, Brazilian fashion remains under consolidation. SPFW has driven Brazilian fashion like a compelling ingredient for economic development. It disseminated the Brazilian fashion style in Brazil and abroad. SPFW is currently organized by Luminosidade, a fashion group that will be discussed later in this chapter. SPFW also contributed to the professionalization of a diverse value chain that involves fashion designers, models, fashion producers, stylists, textile mills, fashion media, etc. SPFW presently features two editions: one in January, anticipating winter collections, and another in July for summer collections. The fashion week investment grew substantially: from US\$600,000 in 1993 to approximately US\$6 - 7 million in recent editions. The number of shows has also increased and reached forty-nine in January 2009 with the entry of new fashion designers. SPFW is now the greatest and most important fashion event in Latin America and can be considered one of the largest fashion weeks in the world among the major fashion weeks: Paris, Milan, London and New York (Pasqual, 2010).

Contemporary Brazilian fashion apparel shows also debuted in Rio de Janeiro in the 1990s. The concept of the Rio de Janeiro event was elaborated by a Brazilian journalist called Eloysa Simão and an Italian architect called Giorgio Knapp. Both realized that a fashion event was essential to attract attention to new collections and gather Brazilian fashion players to think about Rio de Janeiro as a cultural echo of Brazilian fashion. So, the duo launched the Leslie Style Week in 1993. This event was held at the Rio Jockey Club and initially hosted twenty five fashion apparel companies. Three years later, a partnership with Barra Shopping Center moved the fashion event to the mall, remaking and renaming it as Barra Shopping Style Week. At that time investment started to pour into the 
professionalization of the Brazilian fashion industry. During the next six years the Brazilian fashion calendar in Rio revolved around Barra Shopping Style Week (ABIT, 2013; Fashion Design, 2010).

In 2002 Simão and Knapp debuted the Fashion Rio project at the MAM (Museum of Modern Art in Portuguese). At that time the Fashion Rio integrated major initiatives for fashion events in the city of Rio de Janeiro. This was the first time a group of fashion designers were hired by both the public (City Hall) and private sector. It was also the first partnership between fashion apparel companies and textile mills with support from Federation of Industry of the State of Rio de Janeiro in Portuguese (FIRJAN) and Brazilian Textile and Apparel Industry Association in Portuguese (ABIT). Under the umbrella of Fashion Rio most fashion shows were hosted at touristic sights: The Sugar Loaf, Fiscal Island, Copacabana Palace, The National Library and The Lapa District (Fashion Design, 2010).

In May 2009, FIRJAN announced a partnership with InBrands (a Brazilian powerhouse fashion group) and the director and cofounder of SPFW took control of the Fashion Rio. Nowadays, the two most important Brazilian fashion events are coordinated by a fashion group that unified the Brazilian fashion calendar.

São Paulo Fashion Week (SPFW) and Fashion Rio are considered the two most important fashion shows in Brazil. They are the epitome of Brazilian contemporary fashion and their venues attract a wide range of fashion players, such as fashion group representatives, producers, designers, media editors and fashion apparel company directors. They also attract models, stars of music, soap operas, and movies, as well as journalists, celebs, VIPs, architects, artists, fashion students, etc. People who attend fashion shows like to socialize. Some of them come not only to see the shows but also to be seen by the other key players, especially the media players who are responsible for calling attention to people and events, helping make them famous.

\section{Fashion design}

Contemporary fashion design has evolved considerably in the last two decades in Brazil. This role of applying design and aesthetics or natural beauty to apparel has its roots in the 1970s, when some fashion designers such as Zuzu Angel, Lino Villaventura and Gloria Coelho incorporated aspects of Brazilian culture into fashion apparel items.

In the 1980s new fashion design projects appeared, but almost like in the 70s they were proposed in an isolated way, showing that fashion design in Brazil was still incipient. However, these fashion designers had the opportunity to show their work in the newly launched fashion weeks of the 90s. Examples of these fashion design initiatives came from the work of Carlos Miele (M. Officer), Oskar Metsavahat (Osklen), Reinaldo Lourenço, Tufi Duek (Triton and Forum) and Valdemar Iódice.

Some Brazilian fashion designers from the 70s and the 80s studied in fashion schools in Europe and/or in technical fashion schools in Brazil. After 1989, the first graduate fashion design courses appeared. These courses revealed a new generation of recognized Brazilian fashion designers: Alexandre Herchcovitch, Icarius de Menezes, Gisele Nasser, Simone Mina, Adriana Barra, Vinícius Campion (A Mulher do Padre [AMP]), Érica Ikezili, Emilene Galende and Thaís Losso (Cavalera), among others.

One aspect that has been highlighted by some fashion designers in the last years is sustainability. Oskar Metsavahat from Osklen is deeply involved with bringing the idea of simplicity, design and materials from sustainable sources to fashion design. He created the Om.art, a creative design office where his team works with new projects for Brazilian and international partners, such as the new Arpoador watches for the H. Stern jewelry company; the pop art apparel collection (jointly with The Andy Warhol Foundation for the Visual Arts) for the Coca Cola Company; and the Ipanema RJ sandals inspired by the contemporary style of the city of Rio de Janeiro (Osklen, n.d.). Recently, Oskar was invited to join RTG (Runway to Green) a fund-raising project that brings together today's 
most important and relevant fashion designers to raise funds, educate and create awareness for the environment. This project is cosponsored by American Vogue (Runway to Green, 2011).

Some fashion apparel brand names such as Herchcovitch, Lino Villaventura, and Iódice, are highly recognizable in the Brazilian market and designed by a team of designers under the direction of one chief fashion designer, usually the CEO of the fashion apparel retailer and manufacturer (insertion 5). However, the reputation of some companies' brand names, such as Forum (AMC textile), Osklen and Ellus (InBrands) exceed the reputations of their CEOs.

\section{Fashion media}

There are many fashion publications in Brazil. Some of them progressed in the last two decades. Some important fashion magazines are: Vogue Brasil; Elle Brasil; Estilo (InStyle); Marie Claire Brasil; Claudia; Manequim; Mag!; Moda Joyce Pascowitch; L'Officiel Brasil, etc. Certain fashion magazines are published by independent Brazilian media companies; others are published by Brazilian media groups (e.g. Globo and Abril) in association with international media groups such as Condé Nast (Vogue); Time Warner (InStyle); Hachette (Elle). In addition, there are many pages and blogs dedicated to fashion in the internet. Some popular ones are: Fashion forward (http://www.ffw.com.br); Fashion bubbles (http://www.fashionbubbles.com.br); Chic Gloria Kalil (http://www.chic.ig.com.br); Glamurama (http://www.glamurama.uol.com.br); Oficina de Estilo (http://www.oficinadeestilo.com.br), etc. Examples of Brazilian fashion editorials that center attention on Brazilian fashion apparel outfits can be seen in the monthly works of Patricia Carta (2009); Daniela Falcão (2010); Deise Garcia (2010) and Monica Serino (2010).

\section{Fashion groups}

At the present time in Brazil, fashion groups are in a process of consolidation. The best example is Luminosidade from InBrands investment group. Luminosidade was founded by Paulo Borges in the 80 s and was invigorated by other partners in the 2000s. The group's main product is the São Paulo Fashion Week (SPFW), but it also organizes the business meetings surrounding the SPFW. In addition, Luminosidade produces the content of the Fashion Forward website, the Mag! (fashion magazine) and the SPFW Journal. This group also holds the In-Mod - Instituto Nacional de Moda e Design (National Institute of Fashion and Design), the institutional organism of the SPFW.

Another noticeable group is Casa de Criadores (House of Creators). This group is recognized as a breeding ground for new artists (e.g. visual artists, graffitists), graphic designers, photographers and fashion designers. Casa de Criadores has launched and supported fashion designers and their own brand names such as Andre Lima, Carlota Joaquina, Cavalera, Elisa Chanan, Fabia Bercsek, Giselle Nasser, Icarius (fashion designer of Diesel), Juliana Jabour, Jum Nakao, Karlla Girotto, Lorenzo Merlino, Marcelo Quadros, Marcelo Sommer, Mario Queiroz, Ronaldo Fraga, V. Rom, among others. The director of this group, Andre Hidalgo, is also the owner of a prestigious night club in São Paulo called Clube Gloria where he promotes outstanding parties and vernissages (Casa de Criadores, Retrieved http://casadecriadores. uol.com.br/casa-de-criadores, from March 25, 2011).

Other fashion groups (perhaps other ventures) are under construction, including new investments in national and international brand names sponsored by holdings such as Jereissati, Artesia, JHSF, Vicunha and AMC Textile. Some facts related to these industrial groups are shown in the next paragraphs.

There is evidence that these industrial groups are investing in the Brazilian fashion industry. In 2010, Diane Von Furstenberg (DVF) opened her first store in Latin America (Nika, 2010). It is located in Iguatemi São Paulo, a luxury mall that is the location of famous fashion apparel stores such as Christian Louboutin, Louis Vuitton and Chanel. Iguatemi shopping mall belongs to the Jereissati holding company. 
Jereissati holding began its operations in the textile area in the beginning of the last century in Fortaleza, Brazil and, subsequently, diversified its investments in the real estate and metallurgy industries. It currently operates in the telecommunication, service and food sectors and has its headquarters in São Paulo. The Iguatemi Shopping Centers is one of its branches (service) founded in 1973. It is one of Brazil's largest full service companies in the shopping center industry. Its operations comprise project conception, planning, development and management of regional malls and mixed-use real estate complexes such as commercial towers and residential projects in urban areas. Iguatemi São Paulo is the main shopping mall of Iguatemi company (Iguatemi Empresa de Shopping Centers [IESC], n.d.).

Artesia is an investor group which manages its own members' resources. It was founded in 2003 by Brazilian businessmen. At the present time the group holds companies such as Le Lis Blanc (women fashion wear), Metalfrio (commercial freezers) and Produquimica (nutrients for agriculture) (Adachi, 2010).

JHSF holding is a leader in Brazil's real estate industry, with significant operations in development of large-scale and mixed-use residential and office projects; development and management of shopping malls; rentals of office properties; and high-end hotels. The JHSF holding has developed unique expertise in the real estate luxury segment, known for its attractive margins and short payment cycles. One of the large investments of JHSF is the Cidade Jardim mall in São Paulo. Prestigious international brand names (Chanel, Hermès, Giorgio Armani, Jimmy Choo and Salvatore Ferragamo) and national ones (Carlos Miele, Daslu, Reinaldo Lourenço and Valdemar Iódice) are hosted in this luxury shopping mall built and managed by JHSF (JHSF, n.d.).

With more than 40 years in the market, Vicunha is one of the largest textile manufacturers in the world. With factories in Brazil and Ecuador and sales offices in Argentina and Europe (Switzerland), Vicunha occupies a prominent position in the domestic and international markets. Highlighted among its main areas of operation are the production and sales of Indigo and Twill. Vicunha's leadership role in the Brazilian textile market can be verified by several indicators. Currently, it is responsible for $40 \%$ of the Brazilian production of Indigo Denim Fabric, and is also one of the largest producers in the world. Vicunha is one of the main sponsors of SPFW and Casa de Criadores (House of Creators) (Fashion Forward, 2011; Vicunha, 2010).

AMC textile was founded in the 80s in Brusque, Brazil. It is one of the largest producers of knitwear in Brazil. The holding owns some Brazilian fashion apparel retailers and it has been constantly investing in the fashion industry by acquiring new national brand names. At the present time the holding company manages the brands Tufi Duek, Forum, Triton, Forum by Tufi Duek, Colcci, Sommer, Coca Cola Clothing, Carmelitas and Menegotti (AMC Têxtil Ltda, n.d.).

\section{Fashion apparel manufacturers and retailers}

We consider as fashion apparel manufacturers those who design and manufacture their own fashion apparel items. Most of them have their own identity that comprises their own brand.

One example is the fashion apparel manufacturer called Banco de Areia, established in the city of Rio de Janeiro in 1999. Since its beginning, this beachwear manufacturing company embodied its own fashion concept, uprising as an atelier with its own brand-name stores. Visiting Ipanema, the famous and charming Rio de Janeiro beach and neighborhood, one can find ready-to-wear boutiques gathered in a bundle of fashion malls. All these beachwear stores are quite similar, but every window looks for a special market style and fashion. In this scenario, Banco de Areia disseminated own brandname stores. At present the company has 17 retail stores in Rio de Janeiro. The company is expanding its manufacturing and retail activities in the domestic market. It has also operated in the international market since 2003, exporting its own branded products to several countries of the Americas (Canada, Caribbean Islands, Chile, Mexico and USA) Europe (Belgium, France, Holland, Italy, Greece, Portugal and Spain) and Asia (Indian Ocean Islands, Indonesia, Israel, Malaysia and Turkey). Currently, the company manufactures around 40,000 items per month in its plant. More than $20 \%$ of 
its items are exported. Italy and Spain are the main destinations abroad (Pinto, 2009, 2011; Pinto \& Souza, 2011). The main fashion apparel players that provide materials (graphic fabrics) for the company are two textile mills, Rosset and Teka, that specialize in catering to fashion apparel manufacturers.

\section{Textile mills}

Even though textile mills were mentioned in the subcategory of fashion groups, they are seen as part of corporations that are building fashion groups; a distinct player that acts in the fashion apparel chain.

Some textile mills are intrinsically linked to chemical industries and some others are close associated with fashion apparel manufacturers and/or retailers. Textile mills often work with certain patterns of fabric and/or specific pigments that allow fashion apparel manufacturers to be creative when using their materials. At the present time, one of the major challenges faced by textile mills is to become flexible in their production processes, that is, to be capable of manufacturing small and diversified lots of fabric with short lead times. The textile mills are companies that require a huge expenditure in the form of capital and technology. These companies are characterized by economies of scale, since they demand large investments in technology and equipment and are only profitable when maximizing their production output. Traditionally prominent in the Brazilian economy since the beginning of the last century, this sector is dominated by large national and international corporations who have a major influence on the apparel industry.

The Brazilian textile industry is among the 10 largest producers of yarn/threads, woven and knitted fabrics, especially those made from cotton. In this last segment - with a predominance of cotton knits - the country is the third largest producer, only behind the United States and India. Brazilian textile and apparel sectors are the sixth largest producer of textiles and garments in the world. However, in relation to world trade, it is 46th among the major exporting countries and 43rd among the major importers (Costa \& Rocha, 2009). Santa Constancia, AMC Textile, Vicunha and Rosset are among some textile mills that have close relations with fashion apparel manufacturers and/or retailers.

Santa Constancia is an outstanding example of a partnership with the fashion industry. It is an innovative manufacturer of knitted and plain-woven fabrics. The company owns 3 showrooms in São Paulo and Rio de Janeiro. It is a vertically integrated company that transforms raw yarn into finished fabric. Santa Constancia textile mill dyes fabric, draws graphics and produces special texture effects using its exclusive manufacturing processes. It is a Brazilian leader and pioneer in manufacturing natural fabrics with spandex. The company usually supports young fashion designers and renowned Brazilian brand names in their fashion apparel projects. Besides its own collections, the company produces unique graphics in association with its customers: fashion designers, fashion apparel manufacturers and retailers (Santa Constancia, 2011).

\section{Conclusions}

The aim of this study is to contribute to the analysis of the evolution of the apparel industry in Brazil. We considered that the extant literature was not sufficiently explicative to clarify the phenomenon of upgrading in apparel production. Based on this assumption, we addressed different questions at the beginning of this paper. Considering the first ones: Does global sourcing still explain the value upgrading process in the apparel production chains?; and Are there new sources of value upgrading to be considered?, the following comments are appropriate. Initially, the literature related to the cultural and creative economy suggests an alternative view to understand value adding activities related to fashion apparel production. The cultural approach proposes that upgrading in apparel production is related to a process that involves an array of different players who potentially provide 
additional layers or degrees of intangible value to apparel items. This process of upgrading has strong ties with social networking. From this point of view, the initial assumption that upgrading in apparel value chains relies mainly on tangible aspects such as the export models (OEM and OBM) cannot be sustained. The manufacturing approach does not take into account the emergence and influence of a cultural and creative context along the global apparel chains.

Based on the extant theory and on the observed practices as depicted in the previous sections of this paper, we note that upgrading in the apparel industry is explained by the enabling conditions of connections between players responsible for apparel manufacturing and players involved in cultural and creative production. The amalgam of these different players engenders the rise of intermediate players that add tangible and intangible value to apparel production.

Data analyses provided a description of players as well as some connections between them. These players reveal their role in a dynamo that empowers fashion concept and consequently transforms apparel production and consumption. We propose that the whole process implies that different players and their connections should be considered an intermediate fashion apparel chain where intermediate players intertwine with manufacturing players and fashion players. Such a phenomenon could give room for players from emergent countries to add value to their production based on an alternative strategy. Moreover, our data about Brazilian fashion apparel production effectively show that an array of different players related not only to apparel production and retailing, but also to fashion value creation, takes place in the country. The intermediate chain can be characterized as a loose chain and shows that upgrading occurs not only in a tangible value-adding manner but also in an intangible area of mutual and diversified connections between fashion apparel production and consumption. This is a social and cultural-driven system instead of a buyer-driven chain.

Finally we asked if the dynamics of the apparel production are pervaded by a phenomenon that is strongly related to a cultural and creative know-how. We understand that the dynamics of upgrading in the apparel chain discussed herein can have the potential to clarify value-adding processes in products and services where intangible elements and experience represent value to consumers.

As suggestions for further studies we propose the analysis of other cases of apparel production in developing countries and the effects creative and cultural industries have over it. Furthermore, the potential of international entrepreneurship related to emerging fashion hubs should be investigated.

\section{Note}

${ }^{1}$ A preliminary version of this paper was presented at the 27th EGOS Colloquium, Gothenburg, Sweden, July 7-9, 2011.

\section{References}

Abecassis-Moedas, C. (2006). Integrating design and retail in the clothing value chain: an empirical study of the organization of design. International Journal of Operations \& Production Management, 26(4), 412-428. doi: 10.1108/01443570610650567

Abernathy, F. H., Dunlop, J. T., Hammond, J. H., \& Weil, D. (1999). A stitch in time: lean retailing and the transformation of manufacturing: lessons from the apparel and textile industries. New York: Oxford University Press. 
Abernathy, F. H., Volpe, A., \& Weil, D. (2005). The apparel and textile industries after 2005: prospects and choices for public and private actors [Working Paper]. Harvard Center for Textile and Apparel Research, Cambridge, MA.

Adachi, V. (2010, abril 5). Artesia assume banco regional na Flórida. Valor Econômico. Retrieved from http://www.valor.com.br/arquivo/817103/artesia-assume-banco-regional-na-florida

Agência Brasileira de Promoção e Exportações e Investimento. (n.d.). Grupo Moda. Retrieved from http://www.desenvolvimento.gov.br/arquivos/dwnl1259152949.pdf

$\begin{array}{llllll}\text { AMC Textil } & \text { Ltda. } & \text { (n.d.). } & \text { Grupo. } & \text { Retrieved }\end{array}$ http://www.menegotti.com.br/novo_site/por/index.php

Associação Brasileira da Indústria Têxtil e de Confecção. (2013). Monitor ABIT: conjuntura da indústria têxtil e de confecção brasileira. Retrieved from http://www.abit.org.br/adm/Arquivo/Servico/023119.pdf

Berger, S. (2006). How we compete: what companies around the world are doing to make it in today's global economy. New York: Currency Doubleday.

Bonacich, E., \& Waller, D. V. (1994). Mapping a global industry: apparel production in the Pacific Rim triangle. In E. Bonacich, L. Cheng, N. Chinchilla, N. Hamilton, \& P. Ong (Eds.), Global production: the apparel industry in the Pacific Rim (pp. 21-41). Philadelphia, PA: Temple University Press.

Buxey, G. (2005). Globalization and manufacturing strategy in the TCF industry. International Journal of Operations \& Production Management, 25(2), 100-113. doi: $10.1108 / 01443570510576985$

Carta, P. (2009, dezembro). Editorial: um homem e uma mulher. Vogue Brasil, 376, pp. 7-10.

Charmaz, K. (2006). Constructing grounded theory: a practical guide through qualitative analysis. Thousand Oaks: Sage Publications.

Cheng, L., \& Gereffi, G. (1994). U.S. retailers and Asian garment production. In E. Bonacich, L. Cheng, N. Chinchilla, N. Hamilton, \& P. Ong (Eds.), Global production: the apparel industry in the Pacific Rim (pp. 63-79). Philadelphia, PA: Temple University Press.

Cholachatpinyo, A., Padgett, I., Crocker, M., \& Fletcher, B. (2002). A conceptual model of the fashion process - part 1: the fashion transformation process model. Journal of Fashion Marketing and Management, 6(1), 11-23. doi: 10.1108/13612020210422428

Costa, A. C. R. da, \& Rocha, E. R. P. da (2009). Panorama da cadeia produtiva têxtil e de confecções e a questão da inovação (Relatório BNDES Setorial no 29), Rio de Janeiro, RJ, Banco Nacional de Desenvolvimento Econômico e Social.

Currid, E. (2006). New York as a global creative hub: a competitive analysis of four theories on world cities. Economic Development Quarterly, 20(4) 330-350. doi: 10.1177/0891242406292708

Currid, E. (2007). The warhol economy: how fashion, art \& music drive New York City. New Jersey: Princeton University Press.

Dantas, R. J. E. S., Brandão, H. A., Nogueira, J. S., Wosch, L. F. O., Lima, M. F. S., \& Macedo, P. I. R. (2010). Conhecendo o Brasil em números. Brasília: DEPLA, SECEX, MDIC.

Djelic, M-L., \& Ainamo, A. (1999). The coevolution of new organizational forms in the fashion industry: a historical and comparative study of France, Italy, and the United States. Organization Science, 10(5), 622-637. doi: 10.1287/orsc.10.5.622 
Falcão, D. (2010, dezembro). Editorial: celebração merecida. Vogue Brasil, 388, p. 39.

Fashion Design. (2010, maio 31). Fashion Rio. Retrieved from http://mfashiondesign.blogspot.com.br/2010/05/fashion-rio.html

Fashion Forward. (2011, dezembro 15). Terceiro dia da Casa de Criadores mostra novos talentos e desfiles performáticos. Retrieved from http://ffw.com.br/noticias/moda/terceiro-dia-da-casa-decriadores-mostra-novos-talentos-e-desfiles-performaticos/

Ferdows, K., Lewes, M. A., \& Machuca, J. A. D. (2004). Rapid-fire fulfillment. HBR Spotlight. The 21 th. Century Supply Chain. Harvard Business Review, (special suppl.), 104-117.

Garcia, D. (2010, Outubro). Editorial: Parabéns! L'Officiel Brasil, 46, p. 16.

Gereffi, G. (1999). International trade and industrial upgrading in the apparel commodity chain. Journal of International Economics, 48(1), 37-70. doi: 10.1016/S0022-1996(98)00075-0

Gereffi, G., Humphrey, J., \& Sturgeon, T. (2005). The governance of global value chains. Review of International Political Economy, 12(1), 78-104. doi: 10.1080/09692290500049805

Gereffi, G., \& Memedovic, O. (2003). The global apparel value chain: what prospects for upgrading by developing countries? (Sectoral Studies Series). Vienna: UNIDO.

Iguatemi Empresa de Shopping Centers SA. (n.d.). Histórico. Retrieved from http://institucional.iguatemi.com.br/index.php/empresa/historico/

Jacobides, M. G., \& Billinger, S. (2006). Designing the boundaries of the firm: from "make, buy, or ally" to the dynamic benefits of vertical architecture. Organization Science, 17(2), 249-261. doi: $10.1287 /$ orsc. 1050.0167

JHSF. (n.d.). JHSF. Retrieved from http://jhsf.com.br/en/empresa/

Kawamura, Y. (2006). Fashion-ology: an introduction to fashion studies. New York: Berg.

Markusen, A., Wassall, G. H., DeNatale, D., \& Cohen, R. (2008). Defining the creative economy: industry and occupational approaches. Economic Development Quarterly, 22(1), 24-45. doi: $10.1177 / 0891242407311862$

Michault, J. (2009, December 16). H\&M bares its optimistic side. The New York Times, E15. Retrieved from http://www.nytimes.com/2009/12/17/fashion/17H-M.html?_r=0

Nika, C. (2010, May 19). Diane Von Furstenberg: "the future looks best in Brazil". Retrieved from http://www.style.com/stylefile/2010/05/diane-von-furstenberg-the-future-looks-best-in-brazil/

Osklen. (n.d.). Osklen. Retrieved from http://osklen.com/2012/oskar-metsavaht-profile-en/

Pasqual, D. S. (2010). A origem do SPFW. Retrieved from http://sp.fashionweek.com.br/post/65-aorigem-do-spfw/

Pickles, J., \& Smith, A. (2011). De-localization and persistence in the European clothing industry: the reconfiguration of trade and production networks. Regional Studies, 45(2), 167-185. doi: $10.1080 / 00343401003601933$.

Pinto, M. M. B. (2009, setembro). A internacionalização de empresas do setor de vestuário: um estudo sobre uma empresa de moda praia no Brasil. Anais do Encontro Nacional da Associação Nacional de Pós-Graduação e Pesquisa em Administração, São Paulo, SP, Brasil, 33. 
Pinto, M. M. B. (2011). From basic to fashion in the apparel industry: a study about upgrading in value chains (Tese de doutorado). Universidade do Vale do Rio dos Sinos, São Leopoldo, RS, Brasil.

Pinto, M. M. B., \& Souza, Y. S. (2011). A internacionalização de empresas que produzem valor intangível: uma investigação sobre uma empresa brasileira de moda praia. Redige, 2(3), 1-22.

Pontual, M. (2010, outubro 21). Rio de Janeiro por Oskar Metsavaht: estilista lança coleção para Riachuelo. MdeMulher. Retrieved from http://mdemulher.abril.com.br/blogs/modaspotnews/rio-de-janeiro-por-oskar-metsavaht-estilista-lanca-colecao-para-riachuelo/

Pontual, M. (2011, março 16). Cris Barros lança oficialmente sua coleção para a Riachuelo. MdeMulher. Retrieved from http://mdemulher.abril.com.br/blogs/modaspot-news/cris-barroslanca-oficialmente-sua-colecao-para-a-riachuelo/

Porter, M. E. (1990). The competitive advantages of nations. New York: The Free Press.

Prideaux, J. (2009, November 14). Getting it together at last. The Economist [Special Section], p. 3-5.

Rabellotti, R. (2003, April). How globalization affects Italian industrial districts: the case of Brenta. Proceedings of the RSA International Conference, Pisa, Italy.

Rantisi, N. M. (2002). The competitive foundations of localized learning and innovation: the case of women's garment production in New York City. Economic Geography, 78(4), 441-462. doi: $10.1111 / \mathrm{j} .1944-8287.2002 . t b 00195 . x$

Rantisi, N. M. (2004). The ascendance of New York fashion. International Journal of Urban and Regional Research, 28(1), 86-106. doi: 10.1111/j.0309-1317.2004.00504.x

Richardson, J. (1996). Vertical integration and rapid response in fashion apparel. Organization Science, 7(4), 400-412. doi: 10.1287/orsc.7.4.400

Runway to Green. (2011). Runway to Green (RTG) launches an unprecedented effort in partnership with the fashion industry to raise funds and awareness for leading environmental organizations. Retrieved from http://www.runwaytogreen.com/userfiles/DesignerAnnouncement.pdf

Sammarra, A., \& Belussi, F. (2006). Evolution and relocation in fashion-led Italian districts: evidence from two case-studies. Entrepreneurship \& Regional Development, 18(6), 543-562. doi: $10.1080 / 08985620600884685$

Santa Constancia. (2011). Breve histórico. Retrieved from http://santaconstancia.com.br/\#/empresa/breve-historico

Schmitz, H., \& Knorringa, P. (2000). Learning from global buyers. Journal of Development Studies, 37(2), 177-205. doi: 10.1080/713600073.

Serino, M. (2010, outubro). Carta do editor. Marie Claire Brasil, 235, p. 22.

Skov, L. (2006). The role of trade fairs in the global fashion business. Current Sociology, 54(5), 764783. doi: $10.1177 / 0011392106066815$

Trebay, G. (2010, April 28). Needle and thread still have a home. The New York Times, Fashion \& Style, E1, . Retrieved from http://www.nytimes.com/2010/04/29/fashion/29GimletEye.html?pagewanted=all

Tungate, M. (2008). Fashion brands: branding style from Armani to Zara (2nd ed.). London and Philadelphia: Kogan Page. 
Uzzi, B. (1996). The sources and consequences of embeddedness for the economic performance of organizations. American Sociological Review, 61(4), 674-698. doi: 10.2307/2096399

Uzzi, B. (1997). Social structure and competition in interfirm networks: the paradox of embeddedness. Administrative Science Quarterly, 42(1), 35-67. doi: 10.2307/2393808

Vicunha Textil. (2010). Institutional Empresa. Retrieved from http://www.vicunha.com.br/empresa.php

Williams, S., \& Currid-Halkett, E. (2011). The emergence of Los Angeles as a fashion hub: an historical and spatial comparative analysis of New York and Los Angeles' fashion industry. Urban Studies, 48(14), 3043-3066. doi: 10.1177/0042098010392080.

World Bank. (2010). Brazil. Retrieved from http://data.worldbank.org/country/brazil

Yin, R. K. (2006). Estudo de caso: planejamento e métodos (3a ed.). Porto Alegre: Bookman. 